\title{
ANALISIS KEBUTUHAN BAHAN AJAR EDUCATIONAL STATISTICS BERBASIS COOPERATIVE LEARNING
}

\author{
Dwi Astuti \\ Pendidikan Matematika, Fakultas Keguruan dan Ilmu Pendidikan, Universitas Ahmad Dahlan \\ Jl. Ringroad Selatan, Kragilan, Tamanan, Kec. Banguntapan, Bantul, Daerah Istimewa \\ Yogyakarta 55191 \\ *dwi.astuti@pmat.uad.ac.id
}

\begin{abstract}
Abstrak
Mata kuliah statistika pendidikan menjadi salah satu bekal mahasiswa dalam menyelesaikan tugas akhirnya. Saat ini, sudah banyak ditemukan buku tentang statistika, tetapi perlu dianalisis kesesuaian dengan kebutuhan mahasiswa. Penelitian ini bertujuan untuk mengetahui kebutuhan bahan ajar statistika khusus dalam bidang pendidikan. Metode yang digunakan dalam penelitian ini adalah deskriptif kualitatif dengan subjek sebanyak 98 mahasiswa Program Studi Pendidikan Bahasa Inggris Universitas Ahmad Dahlan. Berdasarkan hasil analisis diperoleh bahwa perlu dikembangkan bahan ajar statistika khusus dalam bidang pendidikan. Bahan ajar yang dikembangkan memfasilitasi mahasiswa agar dapat mempelajari contoh-contoh penerapan statistika dalam bidang pendidikan, bahan ajar dikembangkan berdasarkan prinsip pembelajaran cooperative learning sehingga kerjasama antar mahasiswa akan terbentuk, bahan ajar yang dikembangkan merupakan bahan ajar yang interaktif. Bahan ajar yang dikembangkan akan diuji coba pada tahap berikutnya.
\end{abstract}

Kata Kunci: bahan ajar, educational statistika, cooperative learning.

\section{PENDAHULUAN}

Educational Statistics atau Statistika Pendidikan merupakan salah satu mata kuliah wajib pada beberapa Program Studi (prodi) di Universitas Ahmad Dahlan (UAD), sebagai contoh pada Prodi Pendidikan Agama Islam dan Prodi Pendidikan Bahasa Inggris. Materi pada mata kuliah ini menjadi salah satu bekal mahasiswa dalam melakukan analisis tugas akhir. Kemampuan penguasaan materi statistika pendidikan ini menjadi hal yang penting bagi mahasiswa. Berdasarkan hasil observasi di kelas pada awal perkuliahan mata kuliah ini, sebagian besar mahasiswa menyatakan bahwa salah satu alasan mereka memilih program studi yang tidak langsung berkaitan dengan matematika. Sebagian besar dari mahasiswa juga menyatakan bahwa matematika menjadi mata pelajaran yang cenderung tidak disukai sejak jenjang 
sekolah menengah pertama dan sekolah menengah atas.

Hasil Ujian Tengah Semester (UTS) dan Hasil Ujian Akhir Semester (UAS) pada mata kuliah ini menjadi salah satu indikator keberhasilan mahasiswa. Hasil UTS pada pada menunjukkan sebanyak $47,2 \%$ mahasiswa memperoleh nilai di bawah ratarata kelas $(64,3)$. Sedangkan hasil UAS menunjukkan bahwa sebanyak 55,5\% mahasiswa mendapatkan nilai di bawah ratarata kelas (38). Materi yang disampaikan pada mata kuliah ini adalah statistika deskriptif yang meliputi pengumpulan data, penyajian data, ukuran pemusatan data, ukuran penyebaran data, dan ukuran letak data. Materi yang kedua adalah statistika inferensia yang meliputi uji korelasi, persamaan regresi dan uji kebermaknaannya, uji hipotesis dengan uji Z dan uji t.

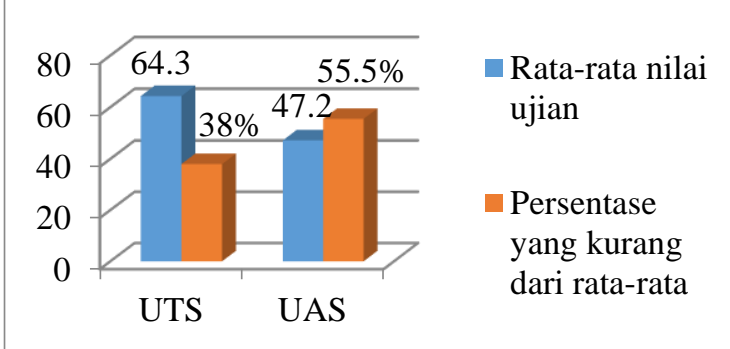

Gambar 1. Nilai rata-rata dan persentase mahasiswa yang mendapat nilai kurang dari rata pada UTS dan UAS

Hasil penilaian mahasiswa terhadap perkuliahan menunjukkan rata-rata skor 35,8 dengan penilaian meliputi beberapa aspek diantaranya metode pembelajaran, ketersediaan sumber belajar, penggunaan media, motivasi, kedisiplinan dalam memulai dan mengakhiri perkuliahan. Nilai yang cenderung rendah ada pada poin ketersediaan sumber belajar atau modul dan metode pembelajaran.
Sumber belajar yang memfasilitasi mahasiswa agar dapat belajar secara mandiri sangat diperlukan agar pembelajaran lebih efektif. Pembelajaran yang berpusat pada mahasiswa (student centered) menjadi hal yang harus diperhatikan dalam pembelajaran di Perguruan Tinggi. Tugas dosen bukan untuk memberikan materi tetapi mahasiswa harus membangun pengetahuannya secara aktif.

\section{Menurut Munadi} penggunanaan media atau sumber belajar akan membantu aktivitas proses pembelajaran terutama dalam peningkatan prestasi atau hasil belajar mahasiswa. Sejalan dengan hal tersebut, Muhaimin (2008), menyatakan bahwa bahan ajar yang menjadi salah satu sumber belajar dapat membantu pendidik dalam melaksanakan pembelajaran. Sedangkan menurut Arlitasari (2013), tujuan penyusunan bahan ajar yaitu 1) membantu mahasiswa dalam memperoleh alternative bahan ajar di samping buku teks yang terkadang sulit dipahami, 2) memudahkan pendidik dalam melaksanakan pembelajaran, 3) menyediakan bahan ajar yang sesuai dengan tuntutan kurikulum dan karakteristik mahasiswa.

Proses pembelajaran yang belum mengakomodir optimalisasi aktivitas mahasiswa dan kerjasama mahasiswa, sehingga hasil belajar mahasiswa akan tergantung pada dosennya. Oleh karena itu, pendidik perlu menerapkan metode pembelajaran yang bervariasi dan memotivasi mahasiswa agar lebih tertarik dalam perkuliahan sehingga akan berdampak pada hasil belajar mahasiswa.

Setelah melihat permasalahan yang ada di kelas tersebut, maka perlu penerapan pendekatan cooperative learning tepat diintegrasikan pada bahan ajar. Cooperative learning memberikan kesempatan kepada mahasiswa untuk aktif dan bekerja sama 
dalam kelompok. Menurut Zakaria dan Iksan (2007), pembelajaran kooperatif menjadi pembelajaran yang efektif saat siswa terlibat aktif dalam berbagi ide dan pekerjaan untuk menyelesaikan tugas akademik. Solusi ini sejalan dengan hasil penelitian Zakaria, Chin, dan Daud (2010) pembelajaran kooperatif dapat meningkatkan prestasi belajar siswa dan sikap siswa terhadap matematika. Hasil tersebut diperkuat dengan pendapat Nurhuda, et al (2018) yang menyatakan bahwa pengembangan perangkat pembelajaran dengan pendekatan kooperatif learning dapat meningkatkan keaktifan peserta didik dan efektif untuk meningkatkan hasil belajar peserta didik.

Arends dan Kilcher (2010: 306) menyatakan bahwap embelajaran kooperatif merupakan model pembelajaran yang dicirikan oleh tugas kelompok, tujuan, dan struktur penghargaan, dan membutuhkan siswa untuk secara aktif terlibat dalam diskusi, debat, latihan, dan kerja sama dalam tim. Slavin (2005: 4) merumuskan bahwa pembelajaran kooperatif mengacu kepada model pembelajaran dimana siswa bekerja dalam kelompok kecil untuk saling membantu mempelajari materi pelajaran. Dalam kelas kooperatif (kelompok) siswa diharapkan untuk saling membantu, berdiskusi, berdebat, saling menilai pengetahuan terbaru dan saling mengisi kelemahan dalam pemahaman masingmasing. Anggota kelompok biasanya terdiri dari empat sampai lima siswa dengan karakteristik yang berbeda-beda seperti jenis kelamin, ras, suku, dan kemampuan. Model cooperative learning menggunakan kelompok yang heterogen khususnya dari kemampuan akademis.

Hal ini sejalan hal di atas Douglas et al. (2009) menyatakan bahwa pembelajaran kooperatif sebagai pengaturan instruksional yang memungkinkan 2-6 siswa berkesempatan untuk bekerja sama dalam berbagi tugas untuk membangun pengetahuan dan pemahaman tentang konten. Senada dengan pendapat Dougals, Robinson (2007) menyatakan bahwa cooperative learning adalah kumpulan strategi instruksional dimana siswa dibentuk dalam kelompok kecil dengan mempertimbangkan interaksi dan kerjasama untuk mempelajari materi pelajaran.

Berdasarkan pemaparan di atas maka perlu dilakukan analisis bagaimana kebutuhan pengembangan bahan ajar statistika pendidikan atau educational statistics.

\section{METODE PENELITIAN}

Metode penelitian yang digunakan adalah metode kualitatif deskriptif. Langkah-langkah dalam penelitian yaitu menentukan topik penelitian, melakukan studi literatur, mengumpulkan data, mengolah data dan menarik kesimpulan. Subjek dalam penelitian ini sebanyak 98 mahasiswa Program Studi Pendidikan Bahasa Inggris yang mengambil mata kuliah educational statistics. Instrumen penelitian yang digunakan adalah kuesioner, pedoman observasi, dan pedoman wawancara. Kuesioner digunakan untuk memperoleh informasi mengenai kesulitan belajar mahasiswa, sumber belajar, dan media yang digunakan. Pedoman observasi digunakan untuk mendapatkan informasi tentang aktivitas mahasiswa dalam kegaitan perkuliahan di kelas. Teknik yang digunakan dalam menganalisis data adalah model Miles and Huberman meliputi data reduction, data display, dan conclusion. Data yang diperoleh kemudian diperkuat dengan wawancara kepada mahasiswa. 


\section{HASIL DAN PEMBAHASAN}

Hasil kuesioner tentang kebutuhan bahan ajar menunjukkan bahwa sebesar $87 \%$ mahasiswa menyatakan bahwa perlu bahan ajar. Hasil kuesioner ditindaklanjuti dengan wawancara. Hasil wawancara menunjukkan bahwa selama ini sudah tersedia buku statistika. Akan tetapi mahasiswa menyampaikan bahwa materi yang disajikan dalam sebagian besar buku tersebut belum sesuai dengan kompetensi yang telah ditetapkan oleh prodi dan harus dicapai oleh peserta. Selain itu, buku yang sudah ada belum menyajikan contoh permasalahan pada bidang pendidikan. Mahasiswa kependidikan akan dihadapkan pada masalah pendidikan di lapangan, sehingga penting bahwa bahan ajar statistika pendidikan sebaiknya menyajikan contohcontoh pada bidang pendidikan. Perlu dikembangkan bahan ajar educational statistics yang disesuaikan dengan karakteristik mahasiswa dan materi.

\section{Analisis Mahasiswa}

Mahasiswa yang menjadi subjek dalam penelitian ini adalah mahasiswa Program Studi Pendidikan Bahasa Inggris yang sedang menempuh mata kuliah educational statistics. Pada awal perkuliahan dosen menanyakan kepada mahasiswa mengapa mahasiswa memilih program studi Pendidikan Bahasa Inggris? Salah satu alasan utama mahasiswa adalah karena mahasiswa tidak ingin bertemu dengan mata kuliah matematika. Ketika mahasiswa mengetahui ada mata kuliah educational statistics maka yang dipikirkan adalah mata kuliah yang isinya hitunghitungan. Karakteristik mahasiswa seperti ini menuntut penyusunan bahan ajar yang tidak memberikan kesan bahwa matematika itu rumit. Dalam penyusunan bahan ajar ini akan ditampilkan contoh soal yang mudah untuk diselesaikan sehingga kesan bahwa matematika itu mudah akan mengubah mindset awal tentang matematika.

Berdasarkan hasil observasi selama proses pembelajaran, seluruh mahasiswa akan memperhatikan penjelasan dari dosen pada menit-menit awal pembelajaran. Setelah pembelajaran berjalan selama lebih dari 15 menit akan terjadi pergeseran fokus mahasiswa. berbeda ketika pembelajaran yang dilakukan adalah pembelajaran yang menuntut mahasiswa berpartisipasi aktif atau menuntut mahasiswa untuk beraktivitas. Berdasarkan karakteristik ini maka bahan ajar dikembangkan secara interaktif dan memfasilitasi terjadinya kolaborasi antar mahasiswa dalam proses pembelajaran.

Selain hal di atas, hasil observasi juga menunjukkan bahwa sebagian besar mahasiswa akan menanyakan ada cara yang lebih praktis atau tidak. Mahasiswa memilih cara yang instan untuk menyelesaikan masalah yang disajikan oleh dosen. Hal ini dapat membatasi kreativitas mahasiswa. Mahasiswa menjadi kurang kreatif dalam menyelesaikan masalah. Berdasarkan hal tersebut, bahan ajar ini dikembangkan untuk memfasilitasi berkembangnya kreativitas mahasiswa melalui penyajian masalah atau melalui penyajian soal sebagai latihan.

\section{Analisis Materi}

Berdasarkan hasil analisis terhadap kompetensi dalam KKNI maka secara umum materi pada mata kuliah educational statistics dibagi menjadi 2, yaitu statistika deskriptif dan staistika inferensia. Materi yang dikembangkan dalam bahan ajar ini adalah statistika deskriptif. Materi yang disajikan dalam bahan ajar ini yang mengembangkan kemampuan kolaboratif dan kemampuan berpikir kreatif mahasiswa. 
Selain itu, materi juga dirancang untuk mengembangkan metakognitif mahasiswa.

Selain materi, tugas-tugas yang diberikan dalam bahan ajar ini merupakan tugas yang berkaitan dengan masalah dalam bidang pendidikan. Perlu ada tugas pada setiap bagian materi agar mahasiswa benarbenar dapat mengukur kemampuan mereka. Hal ini sejalan dengan penelitian Putri (2016) yang menyatakan bahwa bahan ajar yang memuat lebih banyak contoh soal, sehingga mahasiswa dapat mengerjakan latihan soal yang serupa dan apabila diberikan soal yang kemampuannya lebih tinggi maka diharapkan dapat meningkatkan kemampuan pemahaman konsep matematis mahasiswa.

Kerangka buku yang dikembangkan meliputi materi sebagai berikut: (a) pengertian statistika; (b) penyajian data; (c) ukuran gejala pusat data; (d) ukuran letak data; (e) ukuran penyebaran data.

Bahan ajar dikembangkan berdasarkan karakteristik di atas. Masing-masing karakteristik ditunjukkan pada bagianbagian dalam buku sebagai berikut:

a) Masalah yang disajikan pada bahan ajar merupakan masalah yang berkaitan dengan bidang pendidikan. Hal ini bertujuan agar mahasiswa dapat menerapkan ilmunya untuk tugas akhir (tujuan khusus) dan menerapkan ilmu di lapangan ketika menjadi pendidik (tujuan umum).

b) Bahan ajar yang interaktif, bahan ajar ini memfasilitasi terjadinya interaksi dengan mahasiswa atau dengan kata lain buku ini mampu berkomunikasi dengan mahasiswa. Buku yang dikembangkan menggunakan sapaan-sapaan pembaca. Sapaan yang digunakan dalam buku misalnya Coba Anda cermati, mari kita pelajari, coba Anda diskusikan dengan teman Anda, dll. c) Bahan ajar dikembangkan berdasarkan prinsip pada pembelajaran kooperatif. Buku ini memfasilitasi terjadinya kerjasama antar mahasiswa. Ada beberapa bagian buku yang memberikan kesempatan kepada mahasiswa untuk bekerja dalam kelompok.

Contoh soal yang disajikan merupakan contoh soal yang sederhana sehingga kesan yang ada pada mahasiswa bahwa matematika itu sederhana. Kesan ini akan membangkitkan motivasi awal mahasiswa Pendidikan Bahasa Inggris yang awalnya mahasiswa berpikir bahwa matematika itu rumit. Hasil wawancara yang dilakukan terhadap mahasiswa Program Studi Pendidikan Bahasa Inggris menunjukkan bahwa salah satu alasan mereka memilih Program Studi selain Matematika adalah agar tidak bertemu dengan matematika. Sebagian besar dari mereka menilai bahwa matematika itu penuh perhitungan yang rumit. Realitanya ketika mereka bertemu dengan mata kuliah statistika maka mereka pada awalnya bahwa ini merupakan mata kuliah yang tidak mudah karena perhitungannya. Oleh karena itu, latihanlatihan soal yang disajikan dalam buku yang dikembangkan ini merupakan soal-soal yang perhitungannya tidak rumit.

\section{SIMPULAN}

Berdasarkan hasil analisis maka akan dikembangkan bahan ajar educational statistics untuk mahasiswa kependidikan. Karakteristik bahan ajar yang akan dikembangkan yaitu 1) bahan ajar yang menyajikan masalah dalam bidang pendidikan, 2) bahan ajar yang interaktif, 3) bahan ajar dikembangkan berdasarkan prinsip pembelajaran kooperatif, dan 4) 
bahan ajar yang menyajikan contoh soal dari soal sederhana.

\section{DAFTAR PUSTAKA}

Arlitasari, O., Pujiyanto, Budiharti, R. 2013. Pengembangan Bahan Ajar IPA Terpadu dengan Tema Biomassa Sumber Energi Alternative Terbarukan. Jurnal Pendidikan Fisika (11): 82.

Arends, R.I \& Kilcher, A. 2010. Teaching for Student Learning: Becoming an Accumplhised Teacher. New York: Published in the Taylor \& Francis eLibrary

Douglas, F., Frey, N., \& Eferlove, S. 2009. Productive Group Work. Scott Willis: ASCD Alexandria, Virginia USA

Muhaimin, Sutiah, \& Sugeng. 2008. Pengembangan Model Kurikulum Tingkat Satuan Pendidikan pada Sekolah dan Madrasah. Jakarta: PT Raja Grafindo Persada.

Munadi, Y. 2010. Media Pembelajaran. Jakarta: Gaung Persada (GP) Press.
Nurhuda, Lukito, and Masriyah. (2018). Effectiveness of Cooperative Learning Instructional Tools with PredictObserve-Explain Strategy on the Topic of Coboid and Cube Volume. IOP Conf. Series: Journal of Physics: Conf. Series 947 (2017) 012052

Putri, Finola M. 2016. "Pengembangan Bahan Ajar Matematika Dasar Layanan Jurusan Non Eksak". Fibonacci: Jurnal Pendidikan Matematika dan Matematika. Vol. 2 (1), pp: 44-52.

Slavin, R.E. 2005. Cooperative Learning: Theory, Research and Practice. London: Allyn and Bacon.

Zakaria, E., Chin, L.C., \& Daud, Y. 2010. The Effects of Cooperative Learning on Students' Mathematics Achievement and Attitude towards Mathematics. Journal of Social Sciences 6 (2): 272275, 2010 ISSN 1549-3652

Zakaria, E, \& Iksan, Z. 2007. Promoting Cooperative Learning in Science and Mathematics Education: A Malaysian Perspective. Eurasia Journal Math. Sci. \& Tech. Ed., 3(1), 35-39 tahun 2007 